\title{
Livelihood enhancement of tribal farmers through value addition and collective marketing of safed musli (white gold) - A case of Dang district of Gujarat
}

KULDEEP CHOUDHARY, AMIT LATHIYA AND ARVIND RATHOD

Received : 05.02.2015; Accepted : 28.03.2015

\begin{abstract}
The poor farmers had little knowledge of how to market their produce, so they fetched very low price for their produce, sometimes which even ran into losses. The market study hinted at the fact that raw safed musli is unprofitable to sell, so the farmers should go for value addition, like making musli powder, packaging, branding and selling either in wholesale or retail markets. For this in Dang district, some villages have made sincere effort in value addition through purchasing of machineries by jointly /co-operative basis. This effort helped these villages in terms of more production, quality improvement, process improvement and higher earnings. For marketing, villagers have tied up with some retailers. They are also thinking to establish their own wholesale and retail counters at Waghai, Saputara (major tourist centers) and Surat (major market for medicinal plants in south Gujarat). However, to start with, it was decided that farmers would be educated to start collective marketing of safed musli at a better price at terminal markets in India. A number of big traders were identified in Indore, Nasik and Mumbai; their terms and conditions were compared and a trader was finalized. Due to collective marketing the net benefit was found around Rs. 100-250 per kg. of safed musli.
\end{abstract}

KEY WORDS : Value addition, Collective marketing, Livelihood enhancement, Processing, Packaging

How to cite this paper : Choudhary, Kuldeep, Lathiya, Amit and Rathod, Arvind (2015). Livelihood enhancement of tribal farmers through value addition and collective marketing of safed musli (white gold) - A case of Dang district of Gujarat. Internat. J. Com. \& Bus. Manage, 8(1) : 135-138.

Email: kchoudhary@nau.in

\section{Authors' affiliations:}

AMIT LATHIYA AND ARVIND RATHOD, Agriculture Co-operation, Banking and Marketing Polytechnic, Navsari Agricultural University, WAGHAI (GUJARAT) INDIA

Email: arlathiya@nau.in; aprathod@nau.in 